
Wprowadzenie do teorii matematyki ucieleśnionej

\begin{abstract}
Mathematics as a field of knowledge and culture presents researchers with many problems, also of a philosophical nature. One of the issues worth considering when considering the nature of mathematics is the theory of embodied mathematics, which links abstract mathematical thinking with the functioning of the human body in its purely physical dimension. This theory, on the one hand, uncovers new information about the yet unknown neural correlates of mathematics, and on the other hand, it poses important philosophical and cultural questions about the place of mathematics and its role in discovering the rules of reality.
\end{abstract}

Keywords: embodied mathematics, philosophy of mathematics, neurosciences, mathematics

$\mathrm{M}$ atematyka, choć w wielu przejawach używana na co dzień (nieraz zupełnie niezauważalnie, nieintencjonalnie), kojarzona jest z wysokim stopniem abstrakcji, a nawet czymś wzniosłym. Zdarza się, że matematyczne formy podnoszone są do rangi intelektualnych uniesień, a obcowanie z nimi do niemal metafizycznych przeżyć.

Graniczące z poetyckimi opisy piękna matematyki lub kusząca Platońska wizja przedmiotu matematyki jako bytującego samodzielnie, dającego się jedynie odkrywać, a nie konstruować, stoją w opozycji do teorii matematyki ucieleśnionej, wywodzącej się z teorii umysłu ucieleśnionego. Rzeczywistość opisywana jest 
przez matematykę lub daje się przez nią opisać. Czym jednak jest matematyka i jakie jest jej źródło, skoro matematyka kognitywisty nie będzie tą samą co matematyka platonika? Czy piękno matematyki nie zostanie przekreślone wraz z jej zderzeniem z cielesnością?

\section{Matematyka ucieleśniona}

Spór o zewnętrzne lub wewnętrzne pochodzenie matematyki jest sporem czysto filozoficznym. Fakt, że matematyka ma swoje zastosowanie w naukach empirycznych - innymi słowy, że rzeczywistość jest pisana jej językiem, owego sporu nie rozwiązuje. Przyjęcie tego faktu prowadzi bowiem do pytania o to, czy rzeczywistość jest matematyczna (a wówczas łatwiej byłoby przyjąć opcję platonizmu matematycznego i umieścić byty matematyczne jako istniejące poza człowiekiem, bytujące „gdzieś” i mogące być jedynie odkrywanymi, nie konstruowanymi). Jeśli na to pytanie odpowiemy przecząco, nie oznacza to odrzucenia wspomnianej użyteczności matematyki w naukach empirycznych. Możemy się bowiem pochylić nad opcją matematyzowalności świata, a więc nie tyle jego matematycznemu zapisowi, ile możliwości oddania praw rzeczywistości w języku matematyki (a wówczas łatwiej będzie przyjąć opcję konstruktywizmu matematycznego, w myśl którego prawa matematyki są przez nas budowane, nie zaś odkrywane jako bytujące w świecie Platońskich idei).

Warto jednak zaznaczyć, że różnica między matematycznością a matematyzowalnością świata może być sprowadzona do roli sporu wyłącznie językowego, a wręcz pseudoproblemu filozoficznego. Jak pisze Michał Heller:

Niektórzy autorzy zamiast o matematyczności świata, mówią o jego matematyzowalności. W zasadzie różnica pomiędzy tymi dwoma terminami jest taka, jak na przykład między orientowalnością a zorientowaniem powierzchni w geometrii. Orientowalność oznacza możliwość zorientowania: daną powierzchnię można zorientować tylko wtedy, gdy jest ona orientowalna. Ponieważ jednak w moim rozumieniu matematyczności świata, mam na myśli tę jego cechę, dzięki której można go matematycznie badać, różnica pomiędzy matematycznością świata (w moim rozumieniu) a jego matematyzowalnością zaciera się. Wolę jednak używać określenia „matematyczność”, ponieważ zwraca ono uwagę nie tylko na potencjalną skuteczność matematycznego badania świata, lecz podkreśla „fakt dokonany”: metoda ta funkcjonuje i rzeczywiście jest skuteczna ${ }^{1}$.

Kwestie te nie będą w niniejszym tekście analizowane, jednak świadomość ich istnienia uzasadnia rozróżnienie między matematycznością a matematyzowalnością, przyjęte w tych rozważaniach. Heller ${ }^{2}$ zamyka oba te pojęcia w szerszej

${ }^{1}$ M. Heller, Czy świat jest matematyczny, „Zagadnienia Filozoficzne w Nauce” 1998, nr XXII, s. 2, http://www.obi.opoka.org/zfn/022/zfn02201Heller.pdf [dostęp: 18.05.2021].

2 Ibidem. 
kategorii „matematyczności świata”, w której mieści się także fakt, iż matematyka jest użyteczna w naukach empirycznych (stanowisko to można przypisać do szeroko rozumianego realizmu matematycznego ${ }^{3}$ ). To istotne, bo Heller ${ }^{4}$ proponuje eksperyment myślowy, w którym mamy do czynienia ze światami niematematycznymi, tj. takimi, których nie sposób opisać językiem matematyki. W rozróżnieniu przyjętym w niniejszym tekście światy takie byłyby po prostu niematematyzowalne. Dalej Heller rozwija myśl w ten sposób:

Na określenie świata, posiadającego cechę, dzięki której można go badać metodami matematycznymi, będę w dalszym ciągu używał terminu świat poznawczo matematyczny; będę również mówić po prostu o poznawczej matematyczności świata. Natomiast dla światów, które nie są całkowicie niematematyczne [...] zarezerwuję określenie światy ontycznie matematyczne; będę również mówić o matematyczności w sensie ontologicznym. [...] może istnieć świat ontycznie matematyczny, ale nie posiadający cechy poznawczej matematyczności. Stawiam natomiast hipotezę, że matematyczność $\mathrm{w}$ sensie ontologicznym jest koniecznym warunkiem istnienia ${ }^{5}$.

Ontyczna matematyczność jako warunek istnienia implikuje uznanie, że nie ma żadnego świata, żadnej rzeczywistości, która nie byłaby matematyczna. W tym kontekście uprawnione jest pytanie, czy matematyczność jest cechą ontologiczną świata.

Kwestia użyteczności matematyki w naukach empirycznych rozpatrywana jest z wielu punktów widzenia, wielu poziomów. Jednym z nich jest wyżej wymienione założenie poczynione przez Hellera, ale warto przyjrzeć się także innej perspektywie - teorii umysłu ucieleśnionego, w ramach której funkcjonuje teoria matematyki ucieleśnionej.

Nawiązując do myśli Michała Hellera ${ }^{6}$, Mateusz $\mathrm{Hohol}^{7}$ podkreśla, że aby świat był matematyczny, potrzebne są trzy składowe: świat, matematyka i ludzki umysł. To właśnie ten ostatni element jest najbardziej interesujący z punktu widzenia niniejszych rozważań.

Paradygmat matematyki ucieleśnionej (czy szerzej, umysłu ucieleśnionego), stanowi produkt tzw. drugiej generacji kognitywistyki i został zapoczątkowany słynną książką Marka Johnsona i Georga Lakoffa Metafory w naszym życiü. W omawianym paradygmacie zmianie ulega źródło pojęć. Leży ono w ludzkim, cielesnym doświadczeniu. To interakcja człowiek-środowisko tworzy pojęcia:

${ }^{3}$ M. Hohol, Matematyczność ucieleśniona, w: Oblicza racjonalności: wokół myśli Michała Hellera, red. B. Brozek, J. Maczka, W.P. Grygiel, M. Hohol, Copernicus Center Press, Karków 2011, https://hohol.pl/wp-content/uploads/2013/01/hohol_-_matematycznosc_ucielesniona.pdf [dostęp: 18.05.2021].

${ }^{4}$ M. Heller, Czy świat jest matematyczny.

${ }^{5}$ Ibidem, s. 6.

${ }^{6}$ Ibidem.

${ }^{7}$ M. Hohol, Matematyczność ucieleśniona.

${ }^{8}$ Ibidem. 
W paradygmacie ucieleśnionego umysłu znaczenie wywodzone jest z naturalnych doświadczeń oraz interakcji organizmu ze światem zewnętrznym. Umysł wykorzystuje pierwotne struktury znaczące związane m.in. z naturalną orientacją ciała w świecie (dół - góra, przód - tył, centralny - peryferyjny), a następnie za ich pomocą generuje bardziej skomplikowane znaczenia językowe (np. przy użyciu amalgamatów pojęciowych). Procesy te w przeważającej części są nieświadome9.

Metafory pozwalają uzyskać wgląd w te doświadczenia ${ }^{10}$. W związku z faktem, że świat daje się opisać matematycznie (lub jest matematyczny, w sensie przyjętym w tym tekście), nasuwa się pytanie, czy matematyka nie jest metaforą rzeczywistości? Pozostawiam je otwarte. Warto jednak zwrócić uwagę, że owo pytanie, choć pozostawione bez odpowiedzi, skłania do nieco głębszej refleksji nad koncepcją metaforycznej natury języka jako całości (nie tylko języka matematyki). Jak podkreśla Aleksander Gemel, koncepcja ta rozwijana była niezależnie przez dwie tradycje intelektualne: nietzscheańską oraz teorię językoznawstwa kognitywnego ${ }^{11}$. Druga z wymienionych tradycji jest szczególnie interesująca z punktu widzenia rozważań na gruncie filozofii matematyki, a zwłaszcza wątku języka matematyki, ponieważ zawiera interesujący problem konceptualizacji doświadczeń abstrakcyjnych. Jest to temat, nad którym z pewnością warto się pochylić i którego krytykę w sposób szczegółowy przedstawił Gemel ${ }^{12}$. Ze względu na przeglądowy charakter niniejszego tekstu, zarysowana zostanie jedynie obawa o to, że problem konceptualizacji doświadczeń abstrakcyjnych może zachwiać wartością merytoryczną kognitywnej teorii metafor, czego głównym powodem jest relacja schemat-konkretyzacja. Wnikliwą analizę tego problemu przedstawił Gemel. Aby nie zamykać wątku w poczuciu rozbudzonej nadziei, która okazałaby się płonną, warto wspomóc się słowami tego filozofa:

Niezależnie jednak od odpowiedzi na pytanie o celowość metaforycznych odwzorowań nie ulega wątpliwości, że w procesie poznawczo-językowym metafora odgrywa rolę kluczową. Mimo problematyczności podstawowych założeń językoznawstwa kognitywnego do niewątpliwych jego zasług należy jednak zaliczyć ponowne odkrycie metafory dla świata nauki oraz zwrócenie szczególnej uwagi na jej powszechność w życiu codziennym. Dzięki temu metafora okazuje się nieocenionym narzędziem opisu wszelkich dziedzin aktywności ludzkiej, poczynając od prozaicznego wymiaru codziennego funkcjonowania, a na praktyce naukowo-edukacyjnej kończąc ${ }^{13}$.

9 Ibidem, s. 153.

10 Ibidem.

11 A. Gemel, Codzienność metafory w perspektywie kognitywistycznej. Próba krytycznej analizy, „Nauki o Wychowaniu. Studia Interdyscyplinarne” 2016, nr 1(2), http://cejsh.icm.edu.pl/ cejsh/element/bwmeta1.element.hdl_11089_19660/c/nowis2016_Aleksander_Gemel_176_186. pdf [dostęp: 7.08.2021].

12 Ibidem.

13 Ibidem, s. 185. 
Teoria matematyki ucieleśnionej zwraca uwagę na ciało właśnie, a w kontekście kognitywistyki szczególnie na mózg. Jest to paradygmat daleki od hołdowania klasycznemu dualizmowi ciało-umysł (kojarzonemu głównie z Kartezjuszem, choć w tym skojarzeniu należy zachować ostrożność, by nie wpaść w pułapkę niepotrzebnych uproszczeń $\left.{ }^{14}\right)$. Warto zatrzymać się na moment w tym miejscu i wspomnieć o niektórych aspektach filozoficznej polemiki z Kartezjuszem. Jedną z odsłon owej dyskusji jest nurt fenomenologii ucieleśnionej, dalekiej od klasycznego dualizmu Descartes’a. W ramach wspomnianej fenomenologii stawia się pytanie o tożsamość psychofizyczną. Droga do odpowiedzi na to, czym owa tożsamość jest, jak się objawia, bywa fascynującą przygodą z myślą rozmaitych fenomenologów współczesnych (rekonstrukcję tezy o tożsamości psychofizycznej w ramach fenomenologii ucieleśnionej można odnaleźć na przykład w teście Tomasza Kąkola ${ }^{15}$ ). Jednym z przedstawicieli fenomenologii stojącej w opozycji do klasycznego dualizmu, jest francuski filozof Maurice Merleau-Ponty. W swojej myśli zwracał uwagę na istotną kategorię „postrzegania”, stawiając ją naprzeciw klasycznej metafizyce wywodzącej się od Arystotelesa, a rozwijanej w scholastyce ${ }^{16}$. Nie sposób jednak nie wspomnieć, że chcąc ująć myśl Marleau-Ponty’ego w syntetyczny sposób, stawia się go w polemice do Kartezjusza, choć w myśli młodszego z francuskich filozofów nie brakuje odniesień do „ojca nowożytności”. Jak zwraca uwagę Wojciech Starzyński, Merleau-Ponty nie porzuca Kartezjańskiego pojęcia „cogito”"17. Wręcz przeciwnie, próbuje je ocalić, nadając mu własną interpretację. W celu zachowania pojęcia „cogito” fenomenolog analizuje pojęcia uwagi oraz sądu, dochodząc na gruncie analizy myśli Descartes’a do wniosku, że Kartezjusz był blisko opisu naturalnych postrzeżeń (przykładem był choćby obecny w dziełach nowożytnego myśliciela przykład wosku zmieniającego swoje właściwości, a jednak wciąż pozostający woskiem). To dopiero chęć uzyskania pewnej, niezachwianej wiedzy sprowadza Kartezjusza na drogę sankcjonowania postrzeżeń w procesie obiektywizacji ${ }^{18}$. Marleau-Ponty poszukuje nowej interpretacji terminu „cogito”, ostatecznie nie negując wszystkiego, co kartezjańskie. Tak pisze o tym Starzyński:

Pewnym oryginalnym pomysłem autora Fenomenologii percepcji było powiązanie odkrycia cogito z opisem subiektywności ,jedności duszy i ciała” z Medytacji VI, która zarazem potwierdza je i konkretyzuje. W świetle tak uchwyconych kresów fenomeno-

${ }^{14}$ W. Marzęda, Obrona Kartezjusza. O toposie dualizmu w badaniach nad umysłem, „Śląskie Studia Historyczno-Teologiczne” 2018, nr 51(2), ss. 251-262.

${ }^{15}$ T. Kąkol, Fenomenologia ucieleśniona (embodied phenomenology) a teza o tożsamości psychofizycznej, „Edukacja Filozoficzna” 2020, nr 69, DOI: 10.14394/edufil.2020.0002.

${ }^{16}$ M. Szabat, Fenomenalny charakter rzeczy w Fenomenologii percepcji M. Merleau-Ponty'ego, „Principia” 2020, ss. 246-265 [dostęp: 6.08.2021].

${ }_{17}$ W. Starzyński, Czy istnieje „,droga kartezjańska” w „Fenomenologii percepcji” Marleau-Ponty'ego?, „IDEA - Studia nad strukturą i rozwojem pojęć filozoficznych” 2010, nr XXII, https://repozytorium.uwb.edu.pl/jspui/bitstream/11320/1432/1/Idea_2010_22_Starzynski.pdf [dostęp: 6.08.2021].

${ }^{18}$ Ibidem, ss. 87-109. 
logicznej drogi, Merleau-Ponty wskazuje na znaczące fenomenologiczne „prześwity” Medytacji o pierwszej filozofii. Po pierwsze, już na podstawie analizy kawałka wosku można wysnuć wniosek o percepcyjnym charakterze podmiotowości kartezjańskiej, której natura myśląca wyłania się jako część natury w ogóle, czego dowodzą zwłaszcza tzw. sądy naturalne. Po drugie, w świetle fenomenologicznej interpretacji, dotąd dość abstrakcyjna definicja człowieka jako istoty umiejscowionej w porządku ontologicznym pomiędzy Bogiem i nicością oznacza, że podmiotowość może zostać opisana w specyficznej dla niego skończoności, przygodności, jedności z istniejącym światem. Po trzecie, osiągnięcie takiego ontologicznego wymiaru „pośredniego” będzie uzależnione od procedury wątpienia pojętego jednak nie jako zaprzeczenie zewnętrzności, ale radykalny akt, w którym podmiot w swym zaangażowaniu wybiega ku światu jednocześnie siebie ujmując i rozpoznając ostatecznie jako poprzedzające refleksję cogito ${ }^{19}$.

Poczyniony wyżej zwrot ku filozofii, choć jedynie zarysowujący bogactwo polemiki w zakresie dualizmu ciało-umysł, ukazuje głębię tego zagadnienia na gruncie samego poszukiwania „korzeni matematyki”, chętnie rozszerzanego i przenoszonego z filozofii na obszar kognitywistyki czy neurologii.

Neuronalne korelaty matematyki nie są jednoznacznie określone. Badania wciąż trwają, a nauki o mózgu rozwijają się z roku na rok, przynosząc coraz więcej informacji o tym, jak funkcjonuje najmniej poznany z ludzkich organów. Niemniej jednak pewne biologiczne podstawy matematyki są już jasno opisane na mocy konsensusu naukowego.

Można wskazać choćby badania przeprowadzone przez Stanislasa Dehaene i współbadaczy, którzy zwracają uwagę na istnienie trzech systemów reprezentacji, przetwarzających kody liczbowe: od reprezentacji niewerbalnych, pozwalających na określenie odległości lub liczebności, przez reprezentacje werbalne, aż do wizualnych ${ }^{20}$.

Można powiedzieć, że umysłowe reprezentacje liczb u swych fundamentów budowane są na czysto biologicznej, wspólnej ludziom i zwierzętom podstawie ${ }^{21}$, a dopiero stopniowo zyskują nadbudowę kulturową, uwieńczoną reprezentacją symboliczną. Rodzimy się już z podstawową zdolnością do przetwarzania matematycznego ${ }^{22}$. Interesujący jest fakt, że umiejętności, które stoją u podstaw późniejszego budowania kompetencji matematycznych, nie są specyficzne, a związane z ludzkim ciałem, z postrzeganiem świata przez pryzmat ciała właśnie (na przykład zdolność do przestrzennego rozmieszczenia obiektów czy orientacja przestrzenna własnego ciała) ${ }^{23}$.

19 Ibidem, s. 109.

20 S. Dehaene, M. Piazza, P. Pinel, L. Cohen, Three parietal circuits for number processing, „Cognitive Neuropsychology” 2003, no. 20(3/4/5/6), https://www.unicog.org/publications/ DehaeneEtAl_3parietalCircuits_CogNeuropsy2003.pdf [dostęp: 15.05.2021].

21 M. Gut, Kształtowanie umysłowych reprezentacji liczb za pomocq ruchu i gier komputerowych w okresie wczesnoszkolnym, „Annales Universitatis Paedagogicae Cracoviensis. Studia Psychologica” 2019, 12(1).

22 M. Hohol, Matematyczność ucieleśniona.

23 Ibidem. 
Tym, co dobitnie pokazuje nie tylko cielesne, ale i kulturowe zakotwiczenie matematyki, jest tzw. efekt SNARC. Jest on opisywany jako zjawisko przestrzenno-numeryczne związane z szybkością reakcji na liczby. W wielu kulturach, gdzie pisze się i czyta od lewej do prawej strony, szybszą reakcję na duże liczby osiągniemy prawą ręką, a na mniejsze lewą ${ }^{24}$. Efekt ten jest odwrócony w tych kręgach kulturowych, w których czytanie i pisanie odbywa się od prawej do lewej strony. Zasada jednak pozostaje taka sama.

O kulturowym zapośredniczeniu tworzenia Mentalnej Osi Liczbowej niech świadczy fakt, że dwujęzyczność, gdzie w jednym języku obowiązuje czytanie i pisanie od prawej do lewej, a w drugim odwrotnie, może osłabiać efekt SNARC ${ }^{25}$ lub powodować „przełączanie” się efektu SNARC w zależności od tego, w którym z języków czytano tuż przed badaniem efektu SNARC ${ }^{26}$. Oczywiście efekt SNARC bywa przedstawiany jako dowód na kulturowe zapośredniczenie matematyki, a z pewnością skłania do refleksji nad oddziaływaniem kultury, środowiska czy wychowania na nasze procesy poznawcze ${ }^{27}$, ale pokazuje także, że ciało (w tym przypadku orientacja przestrzenna) nie jest czymś obojętnym dla poznania, także matematycznego. Można wręcz uznać, że ciało w owym poznaniu uczestniczy lub nawet niejako je funduje (przynajmniej w pewnych granicach).

Elisabeth Mowat i Brend Davis zwracają uwagę, że matematyka jako dziedzina wiedzy nie jest monolitem, to właściwie konglomerat różnych elementów, które stanowią wciąż ewoluujący system pojęćé . Co warto zaznaczyć, według przywołanych badaczy wiedzę matematyczną możemy zobrazować jako skomplikowaną sieć, której strukturę można odkryć poprzez teorię matematyki ucieleśnionej (stanowiącej swego rodzaju bazę). Mowat i Davis podkreślają także zależność pojęć matematycznych zarówno od metafor (co jest interesujące z punktu widzenia badań nad językiem matematyki czy szerzej, językiem nauki) oraz ucieleśnienia ${ }^{29}$. Owe metafory można potraktować jako przełożenie doświadczeń ciała na język pozacielesny.

${ }^{24}$ S. Dehaene, S. Bossini, P. Giraux, The Mental Representation of Parity and Number Magnitude, „Journal of Experimental Psychology: General” 1993, vol. 122.

${ }^{25}$ Ibidem; K. Patro, W. Krysztofiak, Umysłowe osie liczbowe. Efekt SNARC. Aspekty filozoficzne, „Filozofia Nauki” 2013, 21(3).

${ }^{26}$ S. Shaki, M. Fischer, H.W.M. Petrusic, Reading Habits for Both Words and Numbers Contribute to the SNARC Effect, „Psychonomic Bulletin \& Review” 2009, no. 16, ss. 328-331; K. Patro, W. Krysztofiak, Umysłowe osie liczbowe...

${ }^{27}$ P. Gwiaździński, Czy kultura wpływa na poznanie?, „Filozofia w Praktyce” 2020, nr 6.

${ }^{28}$ E. Mowat, B. Davis, Interpreting embodied mathematics using network theory: Implications for mathematics education, „Complicity: An International Journal of Complexity and Education” 2010, no. 7(1), https://journals.library.ualberta.ca/complicity/index.php/complicity/ article/view/8834/7154 [dostęp: 15.05.2021].

${ }^{29}$ Ibidem. 


\section{Od teorii do praktyki: edukacja matematyczna a matematyka ucieleśniona. Wybrane przykłady}

Umiejętności przestrzenne są bardzo ważne w kontekście edukacji matematycznej. Dysputy filozoficzne, doniesienia kognitywistów czy badania neurologiczne, wnoszą wiele do wciąż rozwijającego się rozumienia fenomenu ludzkiego mózgu a także zdolności matematycznych. Cóż jednak z edukacją? Czy w praktyce można odnaleźć zastosowania dla matematyki ucieleśnionej?

Natalia Witkowska oraz Małgorzata Gut wskazują na badania, które dowodzą korelacji między sprawnością motoryczną dzieci a ich umiejętnościami matematycznymi ${ }^{30}$. Okazuje się bowiem, że ruch jest istotnym elementem, który powinien zostać wdrożony w tok edukacji matematycznej. Badaczki podkreślają, że rola sprawności ruchowej jako predyktora późniejszych umiejętności matematycznych najprawdopodobniej związana jest z umiejętnościami przestrzenno-wzrokowymi. Jak zostało wspomniane na przykładzie efektu SNARC, umiejętności wzrokowo-przestrzenne, są istotne w tzw. myśleniu matematycznym. Sam efekt SNARC można potraktować jako przestrzenną reprezentację liczb. Wzmacnianie owej reprezentacji poprzez użycie gier komputerowych jest wykorzystywane między innymi w terapii dzieci z dyskalkulią oraz jako wsparcie dla dzieci rozwijających się prawidłowo. W tym celu wykorzystywane są na przykład maty taneczne oraz Kinect $^{31}$.

Oprócz efektu SNARC, tym co świadczy o ucieleśnieniu matematyki, jest także liczenie na palcach. Choć różni się ono ze względu na kulturę, samo jego występowanie zdaje się być ponadkulturowe (lub przynajmniej wielokulturowe) ${ }^{32}$. Co więcej, liczenie na palcach dotyczy nie tylko dzieci, a przy tym było obecne na wczesnym etapie filogenezy człowieka. Jak pisze Krzysztof Cipora wraz z innymi badaczami:

Istnieje szereg dowodów wskazujących, że liczenie na palcach pojawiło się w filogenezie człowieka bardzo wcześnie, a ponadto że powstało niezależnie w różnych kulturach i obszarach świata. Pierwsze ślady tego zjawiska, pochodzące sprzed 27 tys. lat, odkryto w jaskini Cosquer we Francji ${ }^{33}$.

${ }^{30}$ N. Witkowska, M. Gut, Znaczenie ruchu w edukacji matematycznej, „Kognitywistyka i Media w Edukacji” 2018, nr 1, https://czasopisma.marszalek.com.pl/images/pliki/kim/2018_1/ kim2018112.pdf [dostęp: 18.05.2021].

${ }^{31}$ M. Gut, Kształtowanie umysłowych reprezentacji...

${ }^{32}$ K. Cipora, M., Szczygieł, M. Hohol, Palce, które liczq - znaczenie liczenia na palcach dla poznania matematycznego u człowieka dorosłego, „Psychologia - Etologia - Genetyka” 2014, t. 30, https://www.tygodnikpowszechny.pl/files/cipora-et-al-palce-ktore-licza_0.pdf [dostęp: 18.05.2021].

${ }^{33}$ Ibidem, s. 61. 
Gnozja palców i poznanie matematyczne są więc ze sobą połączone ${ }^{34}$. Przypuszcza się, że używanie systemu dziesiętnego swoje fundamenty znajduje w liczeniu na palcach ${ }^{35}$.

Istnieje szereg dowodów neurologicznych na znaczenie liczenia na palcach dla umiejętności liczenia (w tym bardzo interesujący zespół Gerstmanna, który wśród wielu objawów charakteryzuje się między innymi dyskalkulią i akalkulią, a także zaburzeniami w orientacji prawo- i lewostronnej ${ }^{36}$ ). Skupianie się na opisywaniu poszczególnych aktywacji mózgu w związku z ciałem i liczeniem nie jest celem niniejszego tekstu. Warto jednak zwrócić uwagę na to, co o liczeniu na palcach, jako swego rodzaju kodzie, piszą Cipora wraz ze współpracownikami:

Istnieje szereg dowodów na to, że układy palców wykorzystywane podczas liczenia stanowią oddzielny rodzaj kodu, w jakim mogą być reprezentowane liczebności. Osoby badane szybciej nazywają liczbę palców na przedstawianych im schematach dłoni, jeżeli wielkości przedstawione są w sposób kanoniczny (tzn. w takim układzie jaki pojawiłby się w czasie liczenia). Co więcej, podprogowa prezentacja układów palców przyspiesza porównywanie liczb w notacji cyfrowej, gdy pryma i bodziec docelowy wywoływały tę samą reakcję ${ }^{37}$.

Widać tu nie tylko wpływ cielesności (w tym przypadku układu palców) na jakość czy szybkość liczenia, ale także specyficzne przełożenie języka ciała na język liczenia. Jest to doskonale widoczne w przypadku wspomnianego zespołu Gerstmanna, w którym w niejako „w parze” występuje problem z nazwaniem liczb oraz nazwaniem palców z nimi związanych ${ }^{38}$. Wspomagające umiejętności matematyczne ćwiczenia praksji są dobrym przykładem wykorzystania teorii w praktyce edukacyjnej. Jak wykazują Tomasz Przybyła oraz Michał Klichowski, do ćwiczeń praksji można wykorzystać współczesne narzędzia informacyjno-komunikacyjne, wśród których wymieniają aplikacje mobilne, a także narzędzia wykorzystujące VR oraz Kincet ${ }^{39}$.

Wspominane wcześniej wykorzystywanie w edukacji matematycznej na przykład mat tanecznych ${ }^{40}$ również stanowi egzemplifikację ucieleśnienia umysłu, w tym matematyki. Ciało pozwala nam na eksplorację otaczającego świata, a także budowanie umiejętności wzrokowo-przestrzennych, tak przecież istotnych

${ }^{34}$ Ibidem; N. Witkowska, M. Gut, Znaczenie ruchu w edukacji...

${ }^{35}$ K. Cipora, M. Szczygieł, M. Hohol, Palce, które liczq...

${ }^{36}$ W. Iwanow, Neurosemiotyka mowy ustnej a funkcjonalna asymetria mózgu, „Teksty Drugie: teoria literatury, krytyka, interpretacja” 2011, nr 1-2(127-128); K. Cipora, M. Szczygieł, M. Hohol, Palce, które liczq̨...

${ }^{37}$ K. Cipora, M. Szczygieł, M. Hohol, Palce, które liczq..., s. 64.

${ }^{38}$ W. Iwanow, Neurosemiotyka mowy ustnej... [dostęp: 18.05.2021].

39 T. Przybyła, M. Klichowski, „Cyfrowe liczby”: Przykłady narzędzi ICT służących kształtowaniu kompetencji matematycznych ucznia poprzez stymulację praksji, 2018, https://repozytorium.amu.edu.pl/bitstream/10593/23544/1/Cyfrowe_liczby.pdf [dostęp: 15.05.2021].

${ }^{40}$ N. Witkowska, M. Gut, Znaczenie ruchu w edukacji... 
w matematyce. Zaburzenia motoryki ciała wpływają negatywnie na kształtowanie kompetencji matematycznych. Co więcej, na procesy poznawcze wpływ mają różne rodzaje ruchów, takie jak praksja, ale także i gestykulacja ${ }^{41}$.

\section{Podsumowanie}

Teoria matematyki ucieleśnionej otwiera szereg wątków, nad którymi można dyskutować z rozmaitych punktów widzenia: filozoficznego, kognitywistycznego, edukacyjnego. Wszystkie one zdają się przenikać, tworząc unikalny konglomerat, który można skategoryzować pod zbiorczą nazwą: umiejętności matematyczne. Skąd się one biorą? Jaką mają genezę? Dlaczego matematyka tak świetnie opisuje świat? To tylko niektóre z pytań, które warto postawić i na które należy szukać odpowiedzi.

W niniejszym tekście dokonany został przegląd ważniejszych wątków składających się na całość zwaną teorią umysłu ucieleśnionego. Każdy z nich mógłby być osobno rozwijany, zwracając uwagę na inne aspekty tego szerokiego zagadnienia.

Z owego przeglądu zdaje się jednak wyłaniać pewna konkluzja, która sprowadza się do stwierdzenia, że współczesna kognitywistyka, a także neuroscience, łamią paradygmat dualizmu ciało-umysł. Nie rozwiązuje to jednak wielu filozoficznych kwestii, spośród których niektóre zostały tu już podniesione. Wręcz przeciwnie, matematyka jako dziedzina wiedzy, kultury (jak choćby wykorzystywane w sztuce piękno symetrii czy figur geometrycznych), a także narzędzie opisu rzeczywistości wciąż jest bogatym źródłem filozoficznych refleksji, takich jak wspominane wcześniej pytanie o pochodzenie bytów matematycznych czy bardzo ważne zagadnienie ontologicznego statusu bytów matematycznych. I być może to również jest jedną ze składowych siły, z jaką fascynuje badaczy, skłaniając do kolejnych eksploracji.

\section{Literatura}

Cipora K., Szczygieł M., Hohol M., Palce, które liczq - znaczenie liczenia na palcach dla poznania matematycznego u człowieka dorosłego, „Psychologia - Etologia - Genetyka” 2014, t. 30, , https://www.tygodnikpowszechny.pl/files/cipora-et-al-palce-ktore-licza_0. pdf [dostęp: 18.05.2021].

Dehaene S., Bossini S., Giraux P., The Mental Representation of Parity and Number Magnitude, „Journal of Experimental Psychology: General” 1993, vol. 122.

Dehaene S., Piazza M., Pinel P., Cohen L., Three parietal circuits for number processing, „Cognitive Neuropsychology” 2003, no. 20(3/4/5/6), https://www.unicog.org/publications/DehaeneEtAl_3parietalCircuits_CogNeuropsy2003.pdf [dostęp: 15.05.2021].

Gemel A., Codzienność metafory w perspektywie kognitywistycznej. Próba krytycznej analizy, „Nauki o Wychowaniu. Studia Interdyscyplinarne” 2016, nr 2(1), http://cejsh.

41 Ibidem. 
icm.edu.pl/cejsh/element/bwmeta1.element.hdl_11089_19660/c/nowis2016_Aleksander_Gemel_176_186.pdf [dostęp: 7.08.2021].

Gut M., Kształtowanie umysłowych reprezentacji liczb za pomocq ruchu i gier komputerowych w okresie wczesnoszkolnym, „Annales Universitatis Paedagogicae Cracoviensis. Studia Psychologica” 2019, nr 12(1).

Gwiaździński P., Czy kultura wpływa na poznanie?, „Filozofia w Praktyce” 2020, nr 6.

Heller M., Czy świat jest matematyczny, „Zagadnienia Filozoficzne w Nauce” 1998, nr XXII, http://www.obi.opoka.org/zfn/022/zfn02201Heller.pdf [dostęp: 18.05.2021].

Hohol M., Matematyczność ucieleśniona, w: Oblicza racjonalności: wokół myśli Michała Hellera, red. B. Brozek, J. Maczka, W.P. Grygiel, M. Hohol, Copernicus Center Press, Karków 2011, https://hohol.pl/wp-content/uploads/2013/01/hohol_-_matematycznosc_ucielesniona.pdf [dostęp: 18.05.2021].

Iwanow W., Neurosemiotyka mowy ustnej a funkcjonalna asymetria mózgu, „Teksty Drugie: teoria literatury, krytyka, interpretacja” 2011, nr 1-2(127-128).

Kąkol T., Fenomenologia ucieleśniona (embodied phenomenology) a teza o tożsamości psychofizycznej, „Edukacja Filozoficzna” 2020, nr 69, DOI: 10.14394/edufil.2020.0002.

Marzęda W., Obrona Kartezjusza. O toposie dualizmu w badaniach nad umysłem, „Śląskie Studia Historyczno-Teologiczne” 2018, nr 51(2).

Mowat E., Davis B., Interpreting embodied mathematics using network theory: Implications for mathematics education, „Complicity: An International Journal of Complexity and Education” 2010, no. 7(1), https://journals.library.ualberta.ca/complicity/index.php/ complicity/article/view/8834/7154 [dostęp: 15.05.2021].

Patro K., Krysztofiak W., Umysłowe osie liczbowe. Efekt SNARC. Aspekty filozoficzne, „Filozofia Nauki” 2013, nr 21(3).

Przybyła T., Klichowski M., „Cyfrowe liczby”: Przykłady narzędzi ICT służq̨cych kształtowaniu kompetencji matematycznych ucznia poprzez stymulację praksji, 2018, https:// repozytorium.amu.edu.pl/bitstream/10593/23544/1/Cyfrowe_liczby.pdf [dostęp: 15.05.2021].

Shaki S., Fischer M. H., Petrusic W.M., Reading Habits for Both Words and Numbers Contribute to the SNARC Effect, „Psychonomic Bulletin \& Review” 2009, no. 16.

Starzyński W., Czy istnieje „droga kartezjańska” w Fenomenologii percepcji Merleau-Ponty’ego?, „IDEA - Studia nad strukturą i rozwojem pojęć filozoficznych” 2010, nr XXII, https://repozytorium.uwb.edu.pl/jspui/bitstream/11320/1432/1/Idea_2010_22_Starzynski.pdf. [dostęp: 6.08.2021].

Szabat M., Fenomenalny charakter rzeczy w „Fenomenologii percepcji” M. Merleau-Ponty'ego, „Principia” 2008, nr 50.

Witkowska N., Gut M., Znaczenie ruchu w edukacji matematycznej, „Kognitywistyka i Media w Edukacji” 2018, nr 1, https://czasopisma.marszalek.com.pl/images/pliki/ kim/2018_1/kim2018112.pdf [dostęp: 18.05.2021]. 
